\title{
THE PAST, PRESENT AND FUTURE OF THE CAMBRIDGE LAW JOURNAL
}

\author{
LIONEL BENTLY*
}

\section{INTRODUCTION}

This introductory essay reviews the history of the Journal, divided into two stages: the period from 1921 to 1953; and that from 1954 to today. It examines the changing institutional arrangements, personnel, as well as some of the highlights in the content of the Journal. If there is a theme, it is that the Journal was established by and developed its reputation because of the efforts of many of the outstanding scholars at Cambridge who over the decades offered the outputs of their talents to the Journal; and that the Journal has used that reputation more and more to attract the scholars outside Cambridge - indeed from all over the world. Whatever the aims of those who established the Cambridge Law Journal in 1921, and without much self-consciousness, the Journal incrementally acquired the status and practices of a learned journal. Finally, the essay reflects on the future, in particular the challenges of digitisation, open access and inclusivity.

\section{II. $1921-53$}

When the Journal was founded in 1921, it was the second scholarly law journal in England; the first, the Law Quarterly Review, having been established in 1885. The Cambridge publication differentiated itself from the Law Quarterly Review because it was operated by the University Law Society (which had itself been formed in 1901). ${ }^{1}$ According to one account, the initiative came from a student, T. Simpson Pedler of Queens' College. ${ }^{2}$ However, while the Journal was founded as a student publication, one

* Editor-in-Chief, 2019-. In preparing this I have benefited greatly from conversations and correspondence with many of those connected with the Journal, in particular Sir John Baker, John Bell, Christopher Forsyth, Cherry Hopkins, David Ibbetson, Roderick Munday, Michael Prichard, Pippa Rogerson and John Spencer. My thanks also go to Helen Waring for collecting together the reports of the Editorial Committee to the Faculty Board since 1984; and to Louise Gullifer, Findlay Stark and Stelios Tofaris for reading and commenting on a draft, or parts, of this article. It is with great regret that as this issue was being planned, former General Editor Len Sealy passed away; and that, as this issue was being completed, former General Editor David Yale also passed on. Address for Correspondence: Faculty of Law, University of Cambridge, Cambridge, CB3 9DZ, UK. Email: CLJ@law.cam.ac.uk.

1 As a result, the Journal is not mentioned a single time in the Faculty's minutes through to 1929.

2 H.A. Hollond, "The Origin of the Law Journal: Introductory Note" [1972] C.L.J. 3; H.A. Hollond, "Arthur Lehman Goodhart" [1964] C.L.J. 1 (the idea "was mooted by some undergraduate members of the University Law Society"). 
should not assume that there was little involvement from "the Faculty". ${ }^{3}$ There was a Faculty editor, initially Arthur Lehman Goodhart, a fellow at Corpus Christi; and, when he gave up (to take over as editor of the Law Quarterly Review), he was succeeded by Sir Percy Winfield (1929-47), followed by Winfield's successor as the Rouse Ball Professor, Stanley Bailey. The model adopted was that of the Harvard Law Review, ${ }^{4}$ which is understandable given the very close links that existed at that point between the Faculty and Harvard. ${ }^{56}$

Harold Hazeltine, the Downing Professor, wrote an introduction to the inaugural issue, in which he positioned the Journal as part of a "legal renaissance" in post-War England generally and Cambridge in particular. ${ }^{7}$ There were thirteen College law societies, all but one of which had been founded after the War. The articles to be featured in the Journal were to be selected from lectures and addresses to "The Cambridge Law Club" (a Faculty association) or the student societies, as well as from the Faculty. Because of the Faculty's connections, the first volume (issues 1-3, covering 1921-23) includes articles by American scholars Joseph Beale and Roscoe Pound (both of Harvard Law School); judges Viscount Haldane and T.E. Scrutton; ${ }^{8}$ Oxford legal historian William Holdsworth; then Solicitor-General, later Master of the Rolls Ernest Pollock (Viscount Hanworth); his cousin the legal scholar Sir Frederick Pollock; as well as the Faculty's own William W. Buckland (the Regius Professor), Courtney Kenny (the Emeritus Downing Professor), Alexander Pearce Higgins (the Whewell Professor of International Law) and Harry Hollond (Reader in English Law, later Rouse Ball Professor). In addition to these articles, each annual volume would contain case notes, book reviews and reports of the law societies within the university (including moot problems).

The sections entitled "recent cases", located after the articles and before the reports from the law societies, were the primary domain of the students. The case notes were short - in the first issue between 200 and 500 words,

3 In formal terms, university Faculties were first established by the Statutes enacted by the Commissioners of 1923, and in 1921 what became known as "Faculty Board" was called the "Board of Legal Studies". I use the term less strictly to refer to the collection of legal scholars employed by the university or colleges at any given time.

4 Hollond, "Origin of the Law Journal"; Hollond, "Arthur Lehman Goodhart". Founded in 1887, the Harvard Law Review set itself rather modest objectives of reporting activities within the School, though the editors said they felt "sure that the contributed articles will prove of permanent value": "Note" (1887) 1 Harv. L.R. 35; (1889) 3 Harv. L.R. 41. For analysis of the structural conditions that informed the emergence of law reviews in the US, see B.J. Hibbitts, "Last Writes? Re-assessing the Law Review in the Age of Cyberspace" (1996) 71 New York University Law Review 615, 617-28.

5 A.L. Goodhart, "The Cambridge and Harvard Law Schools" [1921-23] C.L.J. 323-24; Harold Hazeltine had himself served on the Editorial Board of the 10th and 11th volumes of the Harvard Law Review (1896-98); Henry Hollond had visited Harvard in 1913 to 1914 and Winfield would be visiting Professor at the Harvard Law School in 1923.

6 A.L. Goodhart, "The Origin of the Journal" [1972] C.L.J. 4.

7 H. Hazeltine, "Foreword", [1921] C.L.J. 1. For a description of the Law Faculty prior to the War, see H.A. Hollond and A. McNair, "Some Edwardian Reminiscences" (1970) 1 Cambrian Law Review 43.

8 On Scrutton, see R. Munday [2014] C.L.J. 435 (book review). 
though this increased to a standard 1,000 words in the second and third issues $(1922,1923)$. Most of these notes were provided by the student editors, signed with just their initials (which makes it difficult to be certain as to the identities of some of them). In the first issue, eight of the nineteen notes were by Emlyn C.S. Wade of Caius, who would later be elected as the Downing Professor (1945-62). By the 1923 issue, the case-note section had expanded to some 40 pages, a quarter of that issue.

While the student-writing of the case notes was a key rationale for the Journal, even here, there was a substantial involvement of the Faculty. A specific note editor from the Faculty (distinguished from the General Editor, but until the late forties usually held by the same person) was credited first in 1928. Taking over as sole note editor in 1949 (with Bailey as the General Editor), Charles John ("Jack") Hamson carried through the role until $1953,{ }^{9}$ when student participation in the Journal ceased. No doubt the task of the note editor was to help the increasing number of students involved to select suitable cases, ensure the summaries were correct and their comments appropriate. From an initial seven, student editors had risen to ten in number by 1928, 14 in 1939, 16 in 1944 and 24 in 1952. Writing about Winfield, Lord McNair noted that the role of editor "involved close contact with the student writers of the notes on cases and was very beneficial to them". ${ }^{10}$

Over the first 33 years, the student editors included many who went on to achieve fame in various parts of the legal profession. Gerald Fitzmaurice, a student editor in 1924, would later serve as judge at the International Court of Justice from 1967-73 and the European Court of Human Rights from 1974: ${ }^{11}$ Robert Yewdall Jennings, student editor in 1935, would be made a judge of the International Court of Justice between 1982 and 1995, being president from 1991-94;12 Alexander John Mackenzie Stuart, student editor in 1949, would go on to be the first UK judge on the European Court of Justice, and to serve as its president from 1984-88; Robin Cooke, president of the New Zealand Court of Appeal and later, as Lord Cooke of Thorndon, Lord of Appeal in Ordinary, was a student editor while at Clare College in 1952. In addition to Lord Cooke, many would go on to reach the highest echelons of the English judiciary: Gerald Upjohn, student

9 On Hamson, see Janet Cann, "C.J. Hamson - A Daughter's View" in C.J. Hamson, Liber in vinculis: or, The Mock Turtle's Adventure (Written in Captivity 1941-1945) (Cambridge 1989). Hamson was a prisoner of war between 1941 and 1945. An essay on Hamson's debate with André Tunce is featured in this issue: J. Bell, "Tort Law and The Moral Law: French Law Remains Different" [2021] C.L.J. s33.

10 A. McNair, "Professor Sir Percy Winfield, Q.C, LL.D., F.B.A. (1878-1953)" [1954] C.L.J. 80, 81.

${ }^{11}$ See J.G. Merrills (ed.), Judge Sir Gerald Fitzmaurice and the Discipline of International Law: Opinions on the International Court of Justice, 1961-1973 (The Hague and London 1998) 1-23 (biographical details and an overview of Fitzmaurice's contribution to government, scholarship, the International Law Commission and as a judge of the International Court of Justice).

12 An essay by Jennings, later Whewell Professor of International Law from 1955 to 1981, is the subject of Surabhi Ranganathan's contribution to this issue: S. Ranganathan, "The 'English School' of International Law: Soundings via the 1972 Jubilee Essays" [2021] C.L.J. s126. 
editor in 1926, later Lord Upjohn; Patrick Devlin, on the Editorial Board in 1927, and later Lord Devlin; ${ }^{13}$ Henry Brandon in 1946, later Lord Brandon; Sidney Templeman in 1947, later Lord Templeman; as well as Geoffrey Lane, 1940, Lord Chief Justice from 1980 to 1992.

The student editors also included many who would become important academics: in addition to Emlyn Wade (student editor, 1921 and 1922) and Robert Jennings (student editor, 1935), the Downing and Whewell Professors (1945-62 and 1955-82, respectively), notable examples include Sir Ivor Jennings, student editor in 1925, later Downing Professor (196266), Master of Trinity Hall and Vice-Chancellor; Glanville Williams, student editor in 1933 and later Quain Professor of Jurisprudence at University College, London and Rouse Ball Professor (1968-78); Bill Wedderburn, 1949, later Cassel Professor of Commercial Law at the London School of Economics and editor of the Modern Law Review and, from 1977, a member of the House of Lords; and Sir John C. Smith, a student editor in 1950, and later a celebrated criminal law scholar and "father" of Nottingham Law School. The 1936 and 1937 editorial boards included Arthur Llewellyn Armitage, later President of Queens' College and Vice-Chancellor of the University. ${ }^{14}$

Other student editors achieved fame in other ways. Among the membership of the 1923 Editorial Committee was Harold Abrahams, who won gold in the 100 metres at the 1924 Olympics and whose story was the basis of the film, Chariots of Fire. ${ }^{15}$ He was president of the Caius College Law Club, a frequent mooter and contributor of case notes to the 1922 and 1923 issues. The Editorial Boards for 1948-49 included Harry K.Y. Lee who would, as Lee Kuan Yew, served as Prime Minister of Singapore from 1959 to 1990.

The first 33 years witnessed the publication of some important and influential articles. We have already noted some of the pieces from the first three issues. Some of the contributions were still being referred to at the highest level more than a half-century after they were written. Among these was an article by the recently retired Downing Professor, Courtney Stanhope Kenny, entitled "The Evolution of the Law of Blasphemy". ${ }^{16}$ Published in 1922, this was referred to by the House of Lords in 1979 in its famous ruling in Whitehouse $v$ Lemon concerning a poem by James Kirkup published in the magazine "Gay News" that described Jesus Christ as having been involved in homosexual practices

13 Though at Christ's College, Devlin was supervised by Arthur Goodhart and Harry Hollond: Patrick Devlin, Taken at the Flood (East Harling 1996) 56, 70. As is clear from his autobiography, most of his time was consumed by debating and he graduated with a lower second: ibid., at 72. Although Devlin does not mention the Cambridge Law Journal, after graduating, he was paid money by Goodhart to help with the Law Quarterly Review: ibid., at 75.

14 "Obituary", The Times, 6 February 1984, 16.

15 1981; dir. Hugh Hudson.

16 [1922] C.L.J. 127. 
with his disciples. ${ }^{17}$ In a majority decision $3: 2$ rejecting the editor, Denis Lemon's appeal, the House of Lords held that the crime required only an intention to publish material that was as a matter of fact blasphemous, rather than a showing of an intent to blaspheme. Siding with the majority, Lord Scarman referred to Kenny's "brilliant article", ${ }^{18}$ and used it as a basis for arguing that the law should be extended beyond material offensive to Christians so as to reflect the religiously plural nature of contemporary society. (As it turned out, the offence of blasphemy was abolished by section 79 of the Criminal Justice and Immigration Act 2008.)

Another important article in this period, published in 1932, was co-written by Arthur Goodhart and Jack Hamson entitled "Undisclosed Principals in Contract". ${ }^{19}$ The article sought to explain why, in spite of the doctrine of privity of contract, the law provides that a principal who was at the time of the making of a contract completely unknown to the other party can sue or be sued on the contract of his agent. Goodhart and Hamson sought to explain the rule by analogy with the law on assignment. Sixty-two years later, Lord Lloyd of Berwick, giving judgment for the Privy Council in Siu Yin Kwan v Eastern Insurance Co Ltd., stated that from the extensive literature their "Lordships would especially mention the influential article by Goodhart and Hamson". ${ }^{20}$

The articles exerted influence in other ways, particularly over the best students. One example is Lord McNair's 1931 paper entitled "This Polemis Business", 21 concerning supposed implications for contract of the notorious Court of Appeal decision in Re Polemis. In that case the defendant, who chartered the plaintiff's ship, the Thrasyvoulos, was held liable for all the damage resulting from the negligent act of its stevedores, which led to the destruction by fire of the ship, even though this was not a foreseeable consequence of the stevedores' negligence. ${ }^{22}$ The case, which was effectively overruled by the Privy Council in The Wagon Mound (No. 1), ${ }^{23}$ generated a voluminous literature. ${ }^{24}$ Because the parties to the litigation were parties to a contract, commentators as prestigious as Winfield and Frederick Pollock had suggested the case had altered the rules on remoteness of damages in contract. Presenting the pleadings from the case in detail, Lord McNair demonstrated that the case was one of tort, and while there was no reason a party to a contract should not be

\footnotetext{
${ }^{17}$ [1979] A.C. 617.

18 Ibid., at 658 (Lord Scarman).

19 [1932] C.L.J. 320

20 [1994] 2 A.C. 199,207

21 [1931] C.L.J. 125.

${ }^{22}$ Re Arbitration between Polemis and Another and Furness, Withy \& Co., Ltd. [1921] 3 K.B. 560

${ }^{23}$ Overseas Tankship (U.K.) Ltd. v Morts Dock and Engineering Co. Ltd. (The Wagon Mound (No. 1)) [1961] A.C. 388 (P.C.). See J.A. Weir, "Compensatability for Unforeseeable Damage Resulting Directly from Negligent Acts" (1961) 35 Tulane Law Review 619.

${ }^{24}$ M. Davies, "The Road from Morocco: Polemis through Donoghue to No-fault" (1982) 45 M.L.R 534 ("there are few cases in the history of English law that have attracted more academic attention").
} 
liable to the promisee in tort, the ruling of the Court of Appeal concerned tort and not contract. Percy Winfield took editor's privilege to congratulate Lord McNair on his "a luminous statement of the practical effect of Re Polemis in relation to remoteness of damage in the law of tort and the law of contract", while taking the opportunity to suggest that there were still some wrinkles in McNair's argument. ${ }^{25}$ However, looking back fifty years later, it was clear that the "criticism [of Re Polemis based on its failure to cite leading contract cases such as Hadley $v$ Baxendale] was silenced by McNair". ${ }^{26}$ What is of interest here, however, is less the impact of Lord McNair's analysis on the scholarly debate than the impression that Lord McNair's article made on Robert Jennings, who, as we have already noted, was a student. Jennings would later recall the impact of the article on his understanding of tort:

this writer remembers with affection because, while he was an undergraduate, it shed light for him on the hitherto dark pages of the Polemis case. The article carries the arresting title: "This Polemis Business". This seems to epitomize the McNair approach: urbane; slyly humorous; gently sardonic; an almost architectural sense of the structure and elements of the law; a refusal ever to seek safety and refuge in jargon and obscurity; definitive. ${ }^{27}$

From the start, book reviews were a significant component of the Journal. In the 1930 issue, 35 pages out of 124 were devoted to reviews; in 1951 over 60 pages of a 188-page issue. The reviews themselves were of variable length, depending on the book under review, and many of them might better be described as notes. ${ }^{28}$ A separate book review editor was assigned from 1928. The first was Lord McNair (1928); but after a year the role belonged to David T. Oliver. ${ }^{29}$ From 1938 until the Journal was transferred to the Faculty, Oliver was joined by Dr. Tom Ellis Lewis, the law librarian and lecturer, and understood to have been awarded the first Ph.D. for study of law at Cambridge in $1927 .{ }^{30}$ The reviews were largely written by the Faculty: Harold Hazeltine wrote a staggering 70 reviews, Harry Hollond 57 and Arthur Goodhart himself completed 26. The first, by Professor Alexander Pearce Higgins, the newly appointed Whewell Professor of International Law, was a review of a posthumously published work of his predecessor, Lassa Oppenheim. ${ }^{31}$

\footnotetext{
25 [1931] C.L.J. 125, 145n.

26 Davies, "Road from Morocco", 544.

${ }^{27}$ R.Y. Jennings, "Introduction", Lord McNair: Selected Papers and Bibliography (Leiden 1974) 389, 390.

28 One might note here William Buckland's statement that "it is a good rule that a reviewer should read the book he is reviewing, but it is not always observed": (1932-33) 7 Tulane Law Review 627, 629 (Buckland admitting that he had not read all seven bound volumes of S.P. Scott, The Civil Law (Cincinnati 1932)).

29 On David T. Oliver, see P.H. Winfield, "In Memoriam" [1947] C.L.J. 372.

30 On Ellis Lewis, see W.A.F.P. Steiner, "Dr. Tom Ellis Lewis" (1979) 72 Law Library Journal 342.

31 [1921] C.L.J. 106.
} 


\section{III. $1954-2021$}

At the Journal's inauguration, Hazeltine saw the success of student-run law reviews in the US as "a happy augury for the prosperity of the Cambridge Law Journal". ${ }^{32}$ In the US, and in spite of some famous critiques, ${ }^{33}$ Faculty-run journals would continue to switch to the student-edited model. ${ }^{34}$ In contrast, in 1954 , following a review, ${ }^{35}$ it was decided that the Journal should become a Faculty-run affair. The Faculty Board minutes do not reveal the precise reasons, but Arthur Goodhart would later explain that this was because there were not a sufficient number of students who were able to write case notes of a suitable quality. ${ }^{36}$

As a Faculty publication, the Journal now offered two issues each year. Stanley (S.J.) Bailey, who had succeeded Sir Percy Winfield as editor of the student review in 1948 saw the Faculty journal through its first two issues, ${ }^{37}$ before being replaced by the former Note Editor and Professor of Comparative Law, Jack Hamson. There was a great deal of continuity between the new Journal, published "Under the auspices of the Faculty of Law" and its predecessor. The publisher, Stevens \& Sons Ltd., and printer, the Eastern Press in Reading, continued. ${ }^{38}$

${ }^{32}$ Hazeltine, "Foreword", 3.

33 Most famously, F. Rodell, "Goodbye to Law Reviews" (1936) 23 Virginia Law Review 38 (arguing that law reviews "turn ... out stuff that is not fit to read, on subjects that are not worth the bother of writing about").

34 For example, the Michigan Law Review, established in 1902, which began as a Faculty journal (though supported by ten editorial assistants from the student body) became a primarily student edited journal in 1940 (though with a Faculty advisory board) and is now run by over 100 student editors. "Announcement" (1902) 1 Michigan Law Review 58.

${ }^{35}$ Faculty Board, 14 February 1952, in Sixth Minute Book of the Faculty of Law, University of Cambridge Library, GBR/0265/UA/Min.V.128 (1948-1954), Minute 864(7)(b) (reporting that Hersch Lauterpacht "raised the question of the present position and future developments of the Cambridge Law Journal" and was asked to prepare a memorandum embodying his views. Having received a memorandum, on 31 July 1952 the Board appointed a committee of Lauterpacht, Bailey, Hamson, Ellis Lewis, Wade and Milsom to consider future of the Journal: ibid., Minute 890(6). The report of the committee, which I have not located, was discussed in a meeting of the whole Faculty on 5 March 1953, and there support was given to the report: ibid., Minute 952 (meeting of Faculty), 928(6) (report of meeting to Faculty Board). The Editorial Board was appointed by Faculty Board on 20 May 1953: ibid., Minute 941(4). It was decided "that the Journal and its assets should be vested in trustees for "furthering the study of Law in the Faculty or for the purpose of the journal itself": Faculty Board, 12 November 1953, ibid., Minute 959(8) (a meeting directly after the annual meeting of the Faculty), Minute 996 (2) (appointing the Editorial Committee and agreeing that there would be two issues of the journal each year).

${ }^{36}$ Goodhart, "The Origin", 6. It might be noted that in 2016 the students of the Faculty established their own review, the Cambridge Law Review.

${ }^{37}$ Bailey resigned as editor at Faculty Board on 4 March 1954, but later agreed "to edit the second number of the Cambridge Law Journal, with the assistance of Mr H.W.R. Wade": Faculty Boards, 4 March 1954 and 22 April 1954, Sixth Minute Book of the Faculty of Law, GBR/0265/UA/Min.V.128 (1948-1954), Minute 976(7) (asking Editorial Committee to consider the question of his replacement) and Minute 979. Bailey resigned from the Editorial Committee in 1964: Faculty Board, 15 October 1964, in GBR/0265/UA/Min.V.182 (1962-68).

${ }^{38}$ In the early 1960s, the Faculty reflected on the development of the Journal and after some vacillation, moved publisher to Cambridge University Press: Faculty Board, 28 February 1963: Minute Book of the Faculty of Law, GBR/0265/UA/Min.V.182 (1962-68) (lever arch file); Faculty Board, 25 April 1963: Minute Book of the Faculty of Law, GBR/0265/UA/Min.V.182 (1962-68) ("it had been agreed that it should not be so transferred"); Faculty Board, 26 May 1966: Minute Book of the Faculty of Law, GBR/ 0265/UA/Min.V.182 (1962-68) (Hamson reported that arrangements had been made for publication of 
The book review editor, Ellis Lewis, also carried on that role. Of the seven members of the Editorial Board, six had at one time or another been student editors: S.J. Bailey (1923), C.J. Hamson (1928), E.C.S. Wade (1921, 1922), S.F.C. Milsom (1944), T. Ellis Lewis (1924) and H.W.R. Wade (1939) - the only one who had not was Sir Hersch Lauterpacht, who had not studied in Cambridge. ${ }^{39}$ This connection was not just transitional but continued: three of Hamson's successors as General Editor - S.A. de Smith (a student editor in 1941-42, later Downing Professor, 1970-75, and briefly General Editor in 1973-74), David (D.E.C.) Yale (student editor 1948 and 1950, General Editor from 1974 to 1981) and Michael Prichard (student editor, 1950; General Editor, 1996-2002) - had all served time as student editors, while stalwarts of the Editorial Committee, such as R.N. Gooderson (student editor 1936-37; Editorial Committee, 1961-81, and acting editor of the November 1964 issue), ${ }^{40}$ R.W.M. ("Mickey") Dias [Bandaranaike] (student editor for the 1941, 1942, 1944 issues, later Secretary 1963-64, Assistant Editor from 1965 to 1970 , and co-editor of the 1971 Jubilee edition), John C. Hall (student editor 1947 and 1948, note editor 1963-72, 1988-91) and Tony Jolowicz (student editor, 1950, later a note editor, 1961-2010, though he formally retired in 1993) had also done so.

Although the shift to being run by the Faculty was a significant one, the Journal maintained much of its original structure. The reports of the College law societies (each recounting that so-and-so had delivered his excellent paper to the society) had been omitted after $1924,{ }^{41}$ leaving three sections of articles, case notes and book reviews, as well as the annual report of Cambridge University Law Society. Ellis Lewis continued as book review editor, succeeded in 1960 by John Thornely who carried on the role for 25 years. $^{42}$

\section{A. Case Notes}

The most obvious change was in the case notes. In 1954 the section case notes became "case and comments" and were relocated to the first section of each issue, signalling their premier importance. The rubric's reference "and comments" facilitated the publication of notes on new legislation,

the Law Journal by the University Press). Remarkably, the Eastern Press would remain the printer until 2003. Having been taken over in 2000, various troubles ensued, leading ultimately to a decision to have the Journal printed by the University Press.

${ }^{39}$ Hersch Lauterpacht joined the Faculty in 1938 as the Whewell Professor (though his son, Elihu, had served as a student editor in 1949).

40 Gooderson and Jolowicz joined the Editorial Committee as note editors in place of Professor Emlyn Wade and Dr. William Wade: Faculty Board, Report of Straightforward Business Committee, 12 October 1961, Eighth Minute Book 1960-62 GBR/0265/UA/Min.V.181, Minute 1562(2).

41 Reports of the University Law Society continued until [1991] C.L.J. 580.

42 Thornely was assisted by the Law Librarian, W.A.F.P. (Willi) Steiner from 1963-67 (when he retired) and joined by Sir John Baker in 1972. 
new treaties and reports of law reform bodies. ${ }^{43}$ Indeed, the material commented upon need not itself be "new": in March 2021, the "case and comment" section featured a note on a recently discovered proceeding that had occurred in King's Bench in $1447 .{ }^{44}$ The notes were written largely by Faculty members,${ }^{45}$ including what might be called "junior faculty" such as doctoral student Robin Cooke (later Lord Cooke of Thorndon). ${ }^{46}$ They were aimed at practitioners as well as students. ${ }^{47}$ The notes were frequently lengthier than the student summaries that had featured previously (although the 1,000- or 1,500-word limit would later again become the standard), and fewer in number (11 in each issue in 1955) than in the earlier period. The notes/comments were fully attributed, whereas the students' notes had merely borne their authors' initials. The new rubric also allowed for responses and multiple comments on the same case. For example, both Mickey Dias and Tony Jolowicz offered comments on the Privy Council decision in "The Wagon Mound (No. 1)"48 taking up ten pages of the 1961 issue, ${ }^{49}$ and the 1964 volume contained two very lengthy notes by Jack Hamson and Tony Weir on Rookes $v$ Barnard and Stratford $v$ Lindley, ${ }^{50}$ consuming 28 pages in an issue where the case notes reached from page 159 to $233 .{ }^{51}$ Although the norm has returned to 1,500 words for each case, the note editors retain a flexible approach.

The 1954 issue has two case-note editors, Emlyn and William Wade (1954-60). Over the following decades the number of case-note editors proliferated, in part reflecting increasing specialism within legal academia generally: by 1969 there were five;52 in 1986, seven; in 1991, nine; and in 2008, eleven. Many served for a lengthy period: R.N. Gooderson from 1961 through to his death in 1981; Tony Jolowicz from 1961 until 2010;

43 The second issue of 1954 included two comments on statutory reforms, one by H.W.R. Wade on the Law Reform (Limitation of Actions, etc) Act 1954 and the other by E.C.S. Wade on the Law Reform (Enforcement of Contracts) Act, 1954; the 1955 issue a 10-page comment by F.J. Odgers on the Third Report of the Law Reform Committee: [1955] C.L.J. 1-10. Over the following four decades, over 50 pieces of legislation, five international conventions, and 35 law reform papers were reviewed and critiqued.

44 J.H. Baker, "Indebitatus Assumpsit in 1447" [2021] C.L.J. 39 (on Patrington v Killingholme).

45 That said, the first issue of 1954 started with a lengthy note by "a learned contributor who does not wish to append his name": [1954] C.L.J. 7. See also Anon, "Validity of Exercise of Discretionary Powers" [1955] C.L.J. 135

46 Some case notes were provided by practitioners: J.E.S. Simon, "Evidence Excluded by Considerations of State Interest" [1955] C.L.J. 62, 79 (on Iwi v Montesole [1955] Crim. L.R. 313).

47 [1954] C.L.J. 1.

48 [1961] A.C. 388 (P.C.).

49 R.W.M. Dias, "Negligence - Remoteness - The Polemis Rule" [1961] C.L.J. 23 (tentatively welcoming The Wagon Mound (No. 1)); and J.A. Jolowicz, "The Wagon Mound - A Further Comment" [1961] C.L.J. 30 (criticising The Wagon Mound (No. 1) and preferring a remoteness test based on "directness" of damage).

${ }^{50}$ Rookes v Barnard and Others [1964] A.C. 1129; J.T. Stratford \& Son Ltd. v Lindley [1965] A.C. 269 (H.L.).

51 C.J. Hamson, "A Further Note on Rookes v Barnard" [1964] C.L.J. 159; T. Weir, "Chaos or Cosmos: Rookes, Stratford and the Economic Torts" [1964] C.L.J. 225.

52 These were R.N. Gooderson, Tony Jolowicz, John Hall, Sir Derek William Bowett and Sir David Williams. 
John Hall from 1963 to 1972 and again from 1984 to 1991; Sir David Williams from 1969 to 1993; John Collier from 1983 to 1995; Cherry Hopkins from 1991 to 2009; John R. Spencer from 1986 to 2014; David Fox from 2004 to 2017; Mark Elliott from 2007 to 2018); Albertina Albors-Llorens from 2011 to 2020; some continue to do so - Antje du Bois Pedain (2006-); Janet O'Sullivan (2007-); Louise Merrett (2008-). As the numbers grew, primary responsibility was allocated to a "convening" or "senior note editor" - a role taken successively by John Collier (1991-95), Cherry Hopkins (1996-2006), Graham Virgo (2007-13), David Fox (2014-17), John Allison (2017-19), John Bell (2019), myself (2020) and now David Ibbetson (2021-).

The process of producing the case notes has relied very much on the involvement of the Faculty. To begin, a web of "rapporteurs" are asked to identify important cases to the committee of note editors, who then decide which cases should be noted and who should be approached. The time for writing the notes is short - usually around a month - after which they are scrutinised by the whole committee, which will often insist on revisions. Because time is of the essence, the bulk of the process is carried out most easily "in house", but the note editors will also often approach scholars at other universities and practitioners, including judges. ${ }^{53}$ In addition, the committee considers carefully spontaneous submissions, both to assess the significance of the case and the value of the note. The goal is for the note to combine explanatory clarity with critical insight. Since 2015 each note includes an indication of the note-authors affiliation, by way of an "address for correspondence", irrespective of whether the author is based in Cambridge or elsewhere.

This Centenary Issue contains a review of some of the legendary notes of Tony Weir, ${ }^{54}$ many of which were published as part of a collection. ${ }^{55}$ Len Sealy, who served as the General Editor from 1982-88 (stepping down when he became Chair of the Faculty), recalled Weir's notes in an interview: "they were wickedly funny, often ... there was always a splendid quip or pun or something in just about everything he wrote and the students would fall on his case notes with great glee because I think he just brought a new dimension and a bit of life into what he wrote." 56

While his notes were esteemed for their quality and humour, Tony Weir did not come close to publishing the most notes. According to Nick

\footnotetext{
53 In 2020, Richard Buxton, former Lord Justice of Appeal, contributed two notes: "Consent in Rape: Fact, not Law" [2020] C.L.J. 391; "Vicarious Liability in the Twenty First Century" [2020] C.L.J. 217; and in 2017, Lady Arden wrote a note "Privacy and Third Parties to Court Proceedings" [2017] C.L.J. 469.

54 N. McBride, "Between Chaos and Cosmos: Tony Weir in the Cambridge Law Journal", [2021] C.L.J. s107.

55 C. Barnard et al., Tony Weir on the Case (Oxford 2012).

56 L.S. Sealy in L. Dingle and D. Bates, "Eminent Scholars Archive", available at https://www.squire.law. cam.ac.uk/eminent-scholars-archive (last accessed 11 July 2021).
} 
McBride, ${ }^{57}$ Weir provided 31, which was more than substantial contributors such as Glanville Williams (24), Sir David Williams (26) and David Yale (26), but fewer than the remarkable contributions made by John Collier (36), Sir William Wade (39), John Thornely (41), Len Sealy (53), John Hall (54) and Tony Jolowicz (57). However, at least during the first century of the Journal, the master of the case note numerically was John Spencer who produced a massive 88 case notes. Broadly concerned with crime, tort and human rights, Spencer frequently explained points of equivalent comparative law and sometimes even noted decisions of the courts in France and the Netherlands. ${ }^{58}$ As with Weir, John Spencer's notes were highly regarded both for their wit and incisiveness, ${ }^{59}$ and frequently drew the reader in through references to popular culture, such as the Daily Mirror's cartoon, Andy Capp. ${ }^{60}$ As with Weir, many of them (in fact, 68) came to be separately published as Noted, But Not Invariably Approved. ${ }^{61}$ Introducing the collection, Catherine Barnard referred to them as "a master class in the incisive, engaging note". ${ }^{62}$

The case-note section has long formed an essential part of the Journal, and the notes themselves have frequently proved hugely influential. From the time the Journal became a Faculty one, they were cited in the courts. A few examples from the highest level should provide sufficient evidence. In 1964, Jack Hamson's comment on the first instance decision in Rookes $v$ Barnard was cited approvingly by Lord Devlin in the House of Lords. ${ }^{63}$ In 1975, Colin Turpin's note on a decision of the Appellate Division of the Supreme Court of South Africa was referred to in DPP $v$ Lynch holding a defence of duress was open to a person accused as a principal in the second degree (aider and abettor) to a charge of murder. ${ }^{64}$ In 1994, in $R . v$ Kingston, ${ }^{65}$ concerning involuntary intoxication, Lord Mustill noted that the Court of Appeal's decision had been criticised by academics including by John Spencer who had called the decision "dangerous" and their Lordships allowed the appeal. ${ }^{66}$ In 1995, in Spring $v$ Guardian Assurance plc. ${ }^{67}$ when considering whether a writer of a reference owed a duty of care to the person being refereed, both Lord Slynn and Lord Woolf referred to Tony Weir's note in which he argued the Court of

\footnotetext{
57 McBride, "Between Chaos", s107.

58 [2011] C.L.J. 317; [1993] C.L.J. 306.

59 Or, as one reviewer put it, "a sharp pen and a caustic tongue": G. Renaud, "Noted, But Not Invariably Approved. By J.R. Spencer”. (2016) 41(1) Canadian Law Library Review 32, 32.

60 "Police Officers on Juries" [2012] C.L.J. 254.

61 (Oxford 2014).

62 C. Barnard, "Preface", ibid., 9.

63 [1964] A.C. 1129, 1206-07 (in context of defining tort of intimidation referring to C.J. Hamson, "A Note on Rookes v. Barnard" [1961] C.L.J. 189, 191 as "very persuasive")

64 [1975] A.C. 653, 659 (Lord Edmund Davies) (referring to C.C. Turpin, "Duress and Murders" [1972A] C.L.J. 202 (a note on S. v Goliath (1972) 3 S.A. 1).

65 R. v Kingston (Barry) [1995] 2 A.C. 355 (allowing the appeal), 363 (referring to Spencer).

66 J.R. Spencer, "Involuntary Intoxication as a Defence" [1994] C.L.J. 6.

67 [1995] 2 A.C. 296, 334 (Lord Slynn), 349 (Lord Woolf).
} 
Appeal had been wrong to conclude that such a duty was precluded by the law of defamation - indeed, Lord Woolf said he thought the article "of considerable benefit". ${ }^{68}$ In 2009, in Gray v Thames Trains Ltd., Lord Hoffmann, when considering the doctrine of illegality, quoted from a note by Stathis Banakas, ${ }^{69}$ written in 1985 while he was a doctoral student in Cambridge. ${ }^{70}$

In 2016, in Cox v Ministry of Justice, ${ }^{71}$ affirming Ministry of Justice vicariously liable for the injury caused to one of its officers by the negligence of a prisoner, Lord Reed J.S.C. (with whom all other members of the court agreed) cited John Bell's case note on the Christian Brothers case, ${ }^{72}$ in which Bell systematically dissected Lord Phillips's five-factor analysis of vicarious liability. ${ }^{73}$ Adopting Bell's reasoning that vicarious liability in tort had been effectively equated to a notion of enterprise liability, Lord Reed approved his summary explanation as to why the court had found the Christian Brothers liable. ${ }^{74}$ The following year, in Darnley $v$ Croydon Health Services NHS Trust, ${ }^{75}$ Lord Lloyd Jones J.S.C. (with whom all his colleagues agreed) acknowledged the great assistance he had received from a note on the Court of Appeal decision by James Goudkamp which critiqued that decision as eliding the issue of whether there had been a breach of a duty of care with the distinct question of whether there existed a duty. ${ }^{76}$ More recently, in Vauxhall Motors Ltd. $v$ Manchester Ship Canal Co. Ltd., concerning forfeiture, Lady Arden referred to Peter Turner's "valuable case-note" on the decision of the Court of Appeal. ${ }^{77}$ Finally, in Re Finucane, ${ }^{78}$ Lord Carnwath sought to respond to criticisms, made in a case note by Joanna Bell, of observations he had made in his speech in an earlier case. ${ }^{79}$ Clearly, at least some of the highest members of the judiciary have been reading the case and comment section of the Journal.

68 T. Weir, "The Case of the Careless Referee" [1993] C.L.J. 376.

69 "Tort Damages and the Decline of Fault Liability: Plato Overruled, But Full Marks to Aristotle!" [1985] C.L.J. 195.

${ }^{70}$ [2009] UKHL 33, [2009] A.C. 1339, at [41] (Lord Hoffmann).

71 Cox v Ministry of Justice [2016] UKSC 10, [2016] A.C. 660.

72 The Catholic Child Welfare Society $v$ Various Claimants and the Institute of the Brothers of Christian Schools [2012] UKSC 56, [2013] 2 A.C. 1.

73 J. Bell, "The Basis of Vicarious Liability" [2013] C.L.J. 17.

74 Cox v Ministry of Justice, [2016] A.C. 660, 673, at [31].

75 [2018] UKSC 50, [2019] 2 A.C. 831, 841-42, at [23].

76 J. Goudkamp, "Breach of Duty: A Disappearing Element of the Action in Negligence?" [2017] C.L.J. 480.

77 Vauxhall Motors Ltd. (formerly General Motors UK Ltd.) v Manchester Ship Canal Co. Ltd. [2019] UKSC 46, [2020] A.C. 1161, 1183, at [70] (Lady Arden J.S.C.) (referring to P.G. Turner, "What Delimits Equitable Relief from Forfeiture?" [2019] C.L.J. 276, 279, and quoting the statement that "Equity will only relieve where the security purpose stands ahead of any other").

78 [2019] UKSC 7, [2019] H.R.L.R. 7, at [158].

79 J. Bell, "The Privy Council and the Doctrine of Legitimate Expectation Meet Again" [2016] C.L.J. 449 (criticism of Lord Carnwath's statement in United Policyholders (2016)). 


\section{B. Articles}

While Jack Hamson remained editor of the Journal (that is, until 1973), ${ }^{80}$ the great bulk of the articles initially came from members of the Faculty of Law, or visitors or guest lecturers. The 1968 Journal, for example, contained articles by John Collier, Mickey Dias, R.N. Gooderson, Tony Jolowicz and Tom Hadden (later professor at Queens University, Belfast, but who was then a fellow at Emmanuel College), ${ }^{81}$ as well as guest lectures by Sir Jocelyn Simon that had been given to Trinity Hall Law Society, Sanford Kadish (of University of California, Berkeley) based on a lecture given to the Faculty while a visiting fellow and Bernard Livesey (describing himself as "BA, LLB Peterhouse"). Submissions were certainly subject to significant editorial input by Hamson, as a footnote to Jocelyn Simon's essay explains. Nevertheless, the Journal was far from closed to outside submissions. In fact, the piece by Bernard Livesey was just such an offering: Livesey was not a fellow, nor even a "weekender", but a young barrister who had been incensed by a decision of the House of Lords and wished to express his criticisms. As he recalls, on receiving the submission, Jack Hamson invited him to visit and suggested some typographical corrections. ${ }^{82}$ Similarly, John Baker recollects that he was still at University College, London when, in 1969, the Journal published his "Counsellors and Barristers - An Historical Study". ${ }^{83}$ While the material published in the Journal was in this period dominated by the output of the Cambridge Faculty of Law, this would not have seemed odd or problematic. The reputational incentives for Faculty to publish elsewhere were fewer than they have become and there was a sense of collegiality in providing good copy to support the Journal.

The dominance of local authors in the articles section of the Journal changes most noticeably from the 1970 s, as the Journal became a venue-of-choice for submissions from all quarters. A practice, perceptible but not rigorously adhered to, developed that authors from outside Cambridge should identify their institutional affiliation by way of an "asterisk" after their attribution (while it was assumed to be unnecessary for those associated with the university to disclose that fact). The 1975 volume contained two articles from Cambridge authors (John Spencer and Tony Jolowicz), with five from scholars elsewhere. ${ }^{84}$ In the 1977 volume,

${ }^{80}$ Not with everyone's approval: P. Stein, "Law Reviews and Legal Culture" (1995-96) 70 Part B Tulane Law Review 2675, 2676.

${ }^{81}$ Professor Hadden (now emeritus) is an expert on company law and constitutional law, particularly in relation to Northern Ireland.

82 B. Livesey to L. Bently, email, 28 June 2021.

83 Though he is not described as such in the Journal. Although some scholars from outside Cambridge explicitly identified this by way of footnote, the precise affiliation of many contributors to the Journal remains difficult to discern from the face of the Journal.

84 These were A.W.B. Simpson (Kent), Andrew Ashworth (Manchester), Roy Goode (Queen Mary), Dafydd Jenkins (Aberystwyth) and Garth Nettheim (UNSW). 
alongside three pieces from Cambridge (by Phillip Allott, Kurt Lipstein and Glanville Williams), there were seven pieces from non-Cambridge authors. ${ }^{85}$ Although the precise details of the trajectory are unclear, it is evident that the Journal started gradually to receive (and accept) an increasing number of submissions from outside, associated both with the growth of law faculties in universities and, from the end of the 1980s, a heightened emphasis on publication in reputable journals of which the Journal had become an example (in part because of the excellent content provided by the Faculty over the decades). ${ }^{86}$ In 1995, the practice of identifying the institutional affiliation of authors, by way of an asterisk, was extended to even Cambridge-based authors. This may be thought to symbolise recognition that although the Journal was published "for" the Faculty it was in no sense a vehicle for dissemination of the work "of" Faculty members: it operated fully as a learned journal that was open to and would treat equally submissions from any author.

Given the increase in submissions, in 1985 it was decided that the Journal should be published three times a year and the editorial process became increasingly regularised. Under the editorship of Colin Turpin, it was deemed desirable to add a subeditor in the person of Christopher Forsyth (1991-95), who was given exclusive purview over a new "shorter articles" section when it was introduced in March 1994. ${ }^{87}$ The position of "subeditor" was abandoned when Michael Prichard, retired and thus with fewer work commitments, took over the editorship from 1996 to 2002 (though the "shorter articles" section remains in place).

By the 1990s (and very possibly earlier), it was normal for pieces regarded as potentially publishable to be sent for review. Blind review by two referees became the norm (as it now is with most learned journals) under the editorships of David Ibbetson (2003-09) and John Bell (201019). ${ }^{88}$ The process was streamlined (though not to the liking of all referees)

85 J.G. Merrills (Sheffield); P.H. Pettitt (Bristol); J.W. Harris (Oxford); A. Ogus and G.M. Richardson (Oxford); W. Prest (Adelaide), S.C. Coval and J.C. Smith (British Columbia) and J.V. Capua (University of Chicago).

86 On the growth of universities in England, see Tony Weir, "Recruitment of Law Faculty in England" (1993) 41 A.J.C.L. 335. On the reputation of the Journal amongst UK academics, viewed in terms of the "Research Assessment Exercise", see K. Campbell, D. Vick, A. Murray and G.F. Little, "Journal Publishing, Journal Reputations and the United Kingdom Research Assessment Exercise" (1999) 26 Journal of Law and Society 470, 486 (in answer to question about "the importance to your department of publication in each of the listed journals for purposes of the Research Assessment Exercise" ranking C.L.J. as fifth out of 26).

87 [1994] C.L.J. 1 (announcement). The shorter articles were to be up to 4,000 words in length and they were subject to peer review equivalent to that applied to longer articles. Apparently, the idea was that the additional length was thought desirable in some instances because the 1,000 word limit on case notes was too constraining. The format was initially very popular, and the Journal included nine such articles in both 1994 and 1995. Although the word limit increased to 5,000 words in 2011, the number of shorter articles has diminished.

88 Pressure to change came indirectly as a result of the "Research Assessment Exercise", with respondents to a survey overwhelmingly indicating a desire for blind peer review by legal journals: Campbell et al., "Journal Publishing", 482 ( 83 per cent favouring blind peer review). For a review of the diversity of peer review practices in the humanities and social sciences, see British Academy, Peer Review: The 
when the Journal adopted the ScholarOne system of electronic management of submissions and the refereeing process. There remained - and still remains - a generosity on the part of Cambridge Faculty to support the Journal by submitting their work to it. Today, the Journal is proud to publish the works of our Cambridge colleagues, but they pass through similarly rigorous processes (being subject to blind peer review by two externals); and we are delighted that the Journal remains a title in which our colleagues from other Faculties in the UK as well as the rest of the world are keen to have their writings exhibited.

In 2019, on the retirement of John Bell after a lengthy stint as editor, it was recognised that the job was too onerous for a single person, and thereafter the Journal has had a team of three General Editors (of which I am designated gradiosely "Editor-in-Chief"). In 2020, the Journal received around 250 submissions, sent around 50 articles for review and ultimately published sixteen articles. Rigorous processes for review are absolutely necessary for a generalist journal such as ours, given the growth in legal specialism since the 1990s. Although the core material for the Journal remains the staples of private and public law (tort, contract, equity, restitution, property, criminal law, constitutional law, human rights, administrative law and EU law), as well as legal history, legal philosophy and comparative law, there remains room in a generalist journal for accessible work on company law, environmental law, intellectual property, family law, medical law, banking law, disability law and so on. Moreover, while the Journal recognises the importance of doctrinal legal scholarship, the editors are conscious that important research questions can only properly be answered using appropriate methodologies.

Like the case notes, the articles in the Journal have proved amazingly influential. Most of this Centenary Issue is given over to reflections by six current members of the Faculty of Law (two former editors, Professors David Ibbetson and John Bell, and four other members of the Faculty, Professor Alison Young, Professor Dame Sarah Worthington, Dr. Antje $\mathrm{du}$ Bois Pedain, and Dr. Surabhi Ranganathan) on some of these important interventions by Glanville Williams, Len Sealy, Derek Bowett, Robert Jennings, Sir John Baker, and Christopher Forsyth (all of whom had strong associations with the Journal). There is therefore no need to say anything more here about these works, published between 1962 and 1989. However, I wanted to highlight three other very powerful pieces.

Perhaps the most well-known article - something akin to Warren and Brandeis's Harvard Law Review article on privacy - is H.W.R. Wade's

Challenges for the Humanities and Social Sciences (2007), ch. 2. For a critique of peer review, see B.J. Hibbitts, "Yesterday Once More: Skeptics, Scribes and the Demise of Law Reviews" (1996) 30 Akron Law Review 267, 292-94. 
"The Basis of Legal Sovereignty". 89 This has been described by various scholars as a "famous and very influential article", 90 "one of his most important and enduring contributions to constitutional law",91 as well as "one of the most frequently cited [articles] in British constitutional law and theory". ${ }^{92}$ According to Lord Irvine of Lairg, the article "remains for many the classic exposition of sovereignty theory in the British context". 93 Likewise, Mark Elliott describes the piece as providing "the conventional", 94 "orthodox" or "classic" doctrine of parliamentary sovereignty in the British legal system..$^{95}$ While its status as orthodox or classic hints too at widespread critique and development of alternative or unorthodox views, Wade's account has, of course, been referred to with approval in a number of judicial decisions. ${ }^{96}$

Another important intervention from the Journal - and one, notably, by a scholar not directly linked to the University of Cambridge - was Andrew Ashworth's article entitled "The Doctrine of Provocation". 97 At the time of publication Ashworth was a Senior Lecturer at the University of Manchester, but he would go on to hold the post of Vinerian Professor of Civil Law at Oxford (1997-2013). This exposition of the legal and philosophical underpinnings on the partial defence of provocation to a charge of murder was described by leaders in the field variously as "classic", "famous", "justly celebrated" and "acclaimed". 98 In $R$. v Acott, where the issue before the Lords was whether the judge should have left the question of provocation to be decided by the jury even where there was no evidence of a "provoking" event, Lord Steyn quoted Professor Ashworth's "helpful"

89 [1955] C.L.J. 172. We had hoped to include a full essay discussing the article, but in the end this did not prove possible.

90 P. Eleftheriadis, "Two Doctrines of the Unwritten Constitution" (2017) 13 European Constitutional Law Review 525, 536.

91 R.S. Kay, "Constitutional Change and Wade's Ultimate Political Fact" (2016) 35 University of Queensland Law Journal 31, 31.

92 P.C. Oliver, The Constitution of Independence: The Development of Constitutional Theory in Australia, Canada and New Zealand (Oxford 2005), 93.

93 A.A.M. Irvine, "Sovereignty in Comparative Perspective Constitutionalism in Britain and America" in N. Dorsen (ed.), The Unpredictable Constitution (New York 2001), 325, note 10.

94 M.C. Elliott, "Constitutional Legislation, European Union Law and the Nature of the United Kingdom's Contemporary Constitution" (2014) 10 European Constitutional Law Review 379, 384.

95 M.C. Elliott, The Constitutional Foundations of Judicial Review (Oxford 2001), 14 ("the classic doctrine of sovereignty"), 44-49 ("the Orthodox account").

96 Blackburn v Attorney-General [1971] 1 W.L.R. 1037, 1040 (Lord Denning M.R.); Manuel v Attorney-General [1983] Ch. 77, 89 (Sir Robert Megarry V.-C.); $R$ (Jackson) v Attorney-General [2005] UKHL 56, [2006] 1 A.C. 262, at [120] (Lord Hope); Reference re Secession of Quebec [1998] 2 S.C.R. 217, at [142] (Supreme Court of Canada); Sue v Hill [1999] HCA 30, at [64]; Shaw $v$ Minister for Immigration and Multicultural Affairs [2003] HCA 72, at [12]; Attorney-General (WA) v Marquet [2003] HCA 67, at [63] (High Court of Australia).

97 [1976] C.L.J. 292.

98 T. Macklem and J. Gardner, "Provocation and Pluralism" (2001) 64 M.L.R. 815, 816, note 7 ("classic discussion"), 829, note 25 ("famous"); J. Horder, "Reasons for Anger: A Response to Narayan and Von Hirsch's Provocation Theory" (1996) 15(2) Criminal Justice Ethics 63, 64 ("justly celebrated"); G. Coss, "'God Is a Righteous Judge, Strong and Patient: and God Is Provoked Every Day' A Brief History of the Doctrine of Provocation in England" (1991) 13 Sydney Law Review 570, 594 ("acclaimed"). 
description of "the core features of the modern law of provocation". $99 \mathrm{He}$ drew from the description that there needed to be some evidence of the nature of the provocation, otherwise it would be impossible for the jury to determine whether there was a reasonable justification for feeling aggrieved and thus losing control ("enough to make a reasonable man do as he did").

One aspect of the article that has proved particularly controversial is how far the individual characteristics of a defendant were relevant to a consideration of the reasonableness of the reaction. Ashworth claimed that " $[t]$ he proper distinction ... is that individual peculiarities which bear on the gravity of the provocation should be taken into account, whereas individual peculiarities bearing on the accused's level of self-control should not". ${ }^{100}$ It has been suggested by some that this analysis underpinned that adopted two years later by the House of Lords in R. $v$ Camplin. ${ }^{101}$ Indeed Lord Goff later observed that "the similarity between the approach recommended by Professor Ashworth, and that adopted by the House of Lords ... is so great that it is difficult to believe that his article did not, at least indirectly, influence the reasoning and the conclusion in that case". ${ }^{102}$ While others, including Lord Bingham and Lord Hoffmann, have contested this, ${ }^{103}$ there is no doubt that Ashworth's article informed the Privy Council ruling on appeal from Hong Kong in Luc Thiet Thuan $v$ The Queen, ${ }^{104}$ where Lord Goff reported that their Lordships wished to acknowledge their indebtedness to the article. However, in $R$. $v$ Smith (Morgan), where the House of Lords split (3:2), the majority, while citing the article and recognising its influence, ${ }^{105}$ rejected its analysis. ${ }^{106}$ Finally, the enlarged board of the Privy Council in Attorney General for Jersey $v$ Holley, reiterated the Ashworth analysis, though without citing the article specifically (while the minority did so before rejecting it). ${ }^{107}$ Ashworth's article has also been cited by the Supreme Court of Canada and the High Court of Australia, though the latter adopting a different approach to that in the article. ${ }^{108}$

99 [1997] 1 W.L.R. 306, 311.

100 [1976] C.L.J. 292, 300.

101 [1978] A.C. 705.

102 Luc Thiet Thuan $v$ The Queen [1997] A.C. 131, 141

103 Attorney General for Jersey v Holley [2005] UKPC 23, [2005] 3 W.L.R. 29, at [66] (joint speech).

104 [1997] A.C. 131, 141

105 R. v Smith (Morgan) [2001] 1 A.C. 145, 167 (Lord Hoffmann) ("influential").

106 The majority cite the article at [2001] A.C. 145, 155 (Lord Slynn), 163 (Lord Hoffmann) and 184 (Lord Clyde). The minority, Lord Millett and Lord Hobhouse, refer to it at 214 and 203.

107 [2005] UKPC 23, [2005] 3 W.L.R. 29, at [66] (Lords Bingham and Hoffmann), [72] (Lord Carswell). It seems Ashworth "won the day" when the Coroners and Justice Act 2009, ss. 54-56 abolished the common law of provocation and introduced in its place a partial defence of loss of control in which the circumstances of a defendant were taken into account except "those whose only relevance to D's conduct is that they bear on D's general capacity for tolerance or self-restrain" (s. 54(3)).

108 R. v Cairney [2013] SCC 55, [2013] 3 S.C.R. 420, at [28], [40] (McLachlin C.J. and Rothstein, Cromwell, Moldaver and Wagner JJ.). Cf. Moffa v R (1977) 138 C.L.R. 601, at [12] (Murphy J.) (rejecting Ashworth's analysis of the irrelevance of individual characteristics to the objective element as "too 
The Cambridge Law Journal's most-cited article (according, at least, to one metric), ${ }^{109}$ is Kevin Gray's 1991 piece "Property in Thin Air", an exploration of the concept of "property" from an examination of jurisprudence of its limits. ${ }^{110}$ In a notable opening, Gray asserts that property is not, as Proudhon suggested, theft: it is fraud. The essay goes on to posit that "exclusion" is the most prominent characteristic of the power relationships called "property" and shows that the physical, legal and moral conditions of excludability may vary according to time and circumstance. As a result, the notion of "property" in a resource is not absolute, but relative, and conceptions of property are limited by basic human rights and freedoms. There are distinct moral limits to the concept of "property". David Lametti, then professor of property law at McGill and now Canada's Minister for Justice has described this as a "thoughtful and provocative article", ${ }^{111}$ while others have noted that it is both "influential" 112 and "elegant", but perhaps more importantly that it has opened up ways of "linking property meaningfully to human rights, environmental concerns and a re-imagined relationship between property, inclusion and justice". ${ }^{113}$ Of course, like Wade's theory of legal sovereignty, Gray's thesis that property is fraud has not gone unchallenged. Paul Kohler, for example, devoted a significant part of his Current Legal Problems essay to highlighting what he regards as a fundamental tension in Gray's essay that its "foundations rest upon the essential vacuity of property [but] many of the conclusions point to its central importance". ${ }^{114}$ Even though Professor Gray's essay is primarily theoretical, its impact has not been merely academic, and has been frequently referred to at the highest level in Australia. In Yanner $v$ Eaton, when considering the meaning of "property" in section 7 of Fauna Conservation Act 1974 (Queensland), Gleeson C.J., Gaudron, Kirby and Hayne JJ., giving the majority judgment in the High Court of Australia, cited with approval Gray's observation that "the ultimate fact about property is that it does not really exist: it is mere illusion", 115 using it as a starting point for a limited understanding of section 7. Similarly, Gray's description of property as a "legally endorsed concentration of power" was quoted by the same court in Telstra

refined"); Van Den Hoek v The Queen (1986) 161 CLR 158, at [13] (Mason J., preferring Glanville Williams to Ashworth).

109 "The Cambridge Law Journal - Most Cited", available at https://www.cambridge.org/core/journals/ cambridge-law-journal/most-cited (last accessed 11 July 2021).

110 [1991] C.L.J. 252.

111 D. Lametti, "The Cloud: Boundless Digital Potential or Enclosure 3.0" (2012) 17 Virginia Journal of Law \& Technology 190, 243.

112 M. Davies and N. Naffine, "Response to Commentators" (2003) 28 Journal of Legal Philosophy 221.

113 A. Grear, "Human Rights, Property and the Search for Worlds Other" (2012) 3 Journal of Human Rights and the Environment 173, 186.

114 P. Kohler, "The Death of Ownership and the Demise of Property" (2000) 53 C.L.P. 237, 243.

115 [1999] HCA 53, (1999) 201 C.L.R. 351, at [17]. See also Willmott Growers Group Inc. $v$ Willmott Forests Limited [2013 HCA 51, at [35] (French C.J., Hayne and Kiefel JJ.). 
Corporation Ltd. $v$ The Commonwealth, ${ }^{116}$ as well as in Hocking $v$ National Archive. ${ }^{117}$

\section{Book Reviews}

The Journal has continued to treat book reviews as a vital element. The goal of such reviews has been from the start to describe concisely and evaluate the contribution made by the works under review. As independent assessments of the works under review (the Journal does not commission reviews of books written by members of the Faculty), book reviews have scholarly value in their own right, ${ }^{118}$ but also contribute to the profession by influencing promotion and appointments. ${ }^{119}$ As John Bell wrote, writing such a review is "a genuinely scholarly exercise which makes an important contribution to the legal community". ${ }^{120}$

The reviews in the Cambridge Law Journal have tended to be under 2000 words in length, though the editors have frequently been flexible, especially where more extended treatment is justified. The number of reviews per issue has waxed and waned, though for the last half-century has generally been around 30 pages per issue. There were some bumper years in the late 1980s and early 1990s when Roderick Munday was the book review editor, ${ }^{121}$ of which 1987 was a stand-out year, with reviews of over 80 books in some 130 pages. After something of a decline in the second half of the 2000 s, ${ }^{122}$ probably linked with strategic changes in scholarly writing practices associated with the periodic research audits (the "Research Assessment Exercise" and later "Research Excellence Framework") which were widely understood as not treating reviews as scholarship, ${ }^{123}$ there was a resurgence under the editorship of the late Dr. Catherine Seville. ${ }^{124}$

116 [2008] HCA 7, (2008) 234 C.L.R. 210, 230-31, at [44] (Gleeson C.J., Gummow, Kirby, Hayne, Heydon, Crennan and Kiefel JJ.) (considering whether Telstra's control of so-called "local loops" was property that was protected under s. 51(xxxi) of the Australian Constitution).

117 [2020] HCA 19, at [129] (Kiefel C.J., Bell, Gageler and Keane JJ.) (on the meaning of "a record that is the property of the Commonwealth or of a Commonwealth institution" in the Archives Act 1983).

118 F. Obeng-Odoom, "Why Write Book Reviews?" (2014) 56 Australian Universities Review 78 ("book reviews have a poor status in the academy" but serve "an important role for the reviewer, the author of the book, the scientific community and the general public").

119 M. Adams, "In the Profession: Re-viewing the Academic Book Review" (2007) 35 Journal of English Linguistics 202 (explaining the significance of reviews in promotion).

120 "Catherine Seville" [2016] C.L.J 185

121 1986-98. Dr. Munday remains a trustee, as well as on the Editorial Committee.

122 The section remained strong during the book review editorship of Dr. Pippa Rogerson (1998-2003), but the numbers of reviews declined when Ben Parker (2004-07) and Jake Rowbottom (2008-11) were at the helm. In one year there were only 10 pages of reviews per issue.

123 J.W. East, "The Scholarly Book Review in the Humanities: An Academic Cinderella?" (2011) 42 Journal of Scholarly Publishing 52 (reporting that at least one RAE panel had stated it "will not regard book reviews (as distinct from review articles) ... as demonstrating research activity"). Earlier surveys indicated that legal academics responded strategically to these research audits by changing their research and writing practices: see Campbell et al., "Journal Publishing", 476.

124 Dr. Seville was book review editor from 2012 to 2016 . Her task may have been assisted by the growing cohort of doctoral students in the Faculty, for whom reviewing represents an early opportunity to see their writing published, but Dr. Seville also made significant efforts to identify contributors from beyond the Faculty. 
In the 2014 volume, there were 40 reviews taking up 118 pages. After Dr. Seville's untimely passing, Dr. Peter Turner and Dr. Stelios Tofaris have maintained much of the momentum that she established and the book review section is once again a thriving part of the Journal.

Until at least the $1980 \mathrm{~s}$, the vast majority of reviews were provided by academics at Cambridge or others with close associations with the Faculty. More recently, the book review editors have sought reviewers outside the Faculty, in order to pair the ideal interlocutor with the work under review. Reflecting this (though the shift was taking place long before), since July 2013, the author attribution has been accompanied by the institutional affiliation of the author. In addition to an international array of scholars, recent reviewers include former Australian High Court judges, Bill Gummow and Dyson Heydon; ${ }^{125}$ former Canadian Supreme Court judge, Beverley McLachlin; ${ }^{126}$ Lord Justice Arnold;127 Lord Justice Dingemans; ${ }^{128}$ former High Court judge, Michael Tugendhat; ${ }^{129}$ and New South Wales Judge, Mark Leeming. ${ }^{130}$

\section{THe FutURE}

If the story of the first 100 years is a story of incremental transformation, the future seems to present the possibility of further, possibly more dramatic, change. ${ }^{131}$ Three matters are particularly worthy of comment. The first is the impact of digitisation; the second, the move towards "open access"; the third, the desire to make the Journal more inclusive.

Of course, digitisation is nothing new. It is now a quarter of a century since the advent of the "world wide web", and at least a decade longer since the widespread availability and use of word processors. In that time, the Journal has already responded to many of the opportunities presented by the digital technology both in terms of the production of the Journal and its distribution. There can be no question that digitisation has presented huge benefits for those involved in producing journals. As Michael Prichard, General Editor from 1996 to 2002 explained: "over his tenure at the $C L J$ the tempo of the editorial operation completely changed - it started in an era when physical copy could take three weeks or more to journey to Australasia and back by airmail, to a time when the turnaround for corrections and queries could be measured in a few days, or even hours." 132

131 For a prediction of the demise of law reviews, see Hibbitts, "Last Writes?" ("The next decade could witness the end of the law review as we know it").
} 
As already mentioned, the Journal now receives submissions, seeks and receives referees' reports and issues decisions electronically. With referees given a month, a fully-informed decision will often be made within two months of receipt of the submission, often with the benefit of the views of international experts. In terms of distribution, the Journal has been quick to take advantage of the opportunities digitisation has provided for broader dissemination. In 2003, the Journal editors were already in discussions with HeinOnline about featuring the Journal on that platform. In 2006, an agreement was made with JSTOR (to which the Journal was added in 2008). That same year, it was agreed to include in Cambridge University Press's digital archive.

The rise of "blogging" has presented different challenges. Blogs allow for very speedy summaries and comments on cases, and one might imagine raise questions as to the continued value - and even viability - of "case notes". Coming out only three times a year necessarily means the Journal reacts more slowly than a blog can, and the production process delays matters further: from submission of manuscript, it will be at least two months before a case note appears in print (or on-screen). Not surprisingly, many scholars prefer to use blogs rather than offer the Journal case notes. After some reflection, however, the Editorial Committee has decided there is still an important role for case notes. In contrast with most blogs, where authors battle to be the first to summarise a case, a case note in the Journal allows for a longer period of reflection and requires something more than mere description. In contrast with many blogs, where authors resort to multiple quotations from judgments, in CLJ case notes authors seek to summarise the reasoning of the court as concisely as feasible. Most importantly, in contrast with most blogs, the Journal features only cases that are carefully selected and invites contributors with relevant expertise. ${ }^{133}$ For the moment, there continues to be evidence that case notes in the Journal maintain a stature that most blogs could only envy. This is not to critique blogs - just to recognise that they have a different role, and that their prevalence is not regarded as a significant challenge to the usefulness of case notes. ${ }^{134}$

The second challenge facing the Journal is the growing pressure towards open access publishing, that is, the publishing in a form that allows access to all. Like the matter of "digitisation", "open access" can hardly be said to

${ }^{132}$ L. Dingle and D. Bates, "Mr Michael J Prichard", available at https://www.squire.law.cam.ac.uk/ eminent-scholars-archive/mr-michael-j-prichard (last accessed 11 July 2021).

133 B. Leiter, "Why Blogs Are Bad for Legal Scholarship" 116 Yale L. J. Pocket Part 53, 57 (2006) ("[Blogs] have been bad for legal scholarship, leading to increased visibility for mediocre scholars and half-baked ideas and to a dumbing down of standards and judgments").

134 C.R. Sunstein, "In Praise of Law Books and Law Reviews (and Jargon-filled Academic Writing)" (2016) 114 Mich. L.Rev. 833 ("when law professors write blog posts, they are usually too glib, cheap, conclusory, and superficial to be published in law reviews. That's not an objection to blogs; they have a distinct audience of their own"). 
be a new phenomenon. ${ }^{135}$ Indeed, the open access movement is normally traced back to the "Budapest Open Access Initiative" in 2002. By 2012, open access became government policy as a result of the Finch Report. The report envisaged publication of publicly-funded research in open access or hybrid journals, funded by so-called "article processing charges" (APCs). ${ }^{136}$ In due course, HEFCE required that, irrespective of whether they were research council-funded or not, journal publications could only be included in the 2020 Research Excellent Framework where they had been made accessible in either "gold" open access (i.e. immediately available through payment of an APC) or "green" open access (i.e. made available in an institutional repository after an embargo period).

The implications for any journal are both editorial and financial. In editorial terms, no journal can claim to be publishing the best work in the field unless it is willing to allow publication in open access. The Cambridge Law Journal therefore had no choice but to become a "hybrid journal", that is, if it accepts an article for publication, it is possible for the author to pay an "article processing charge" and make the article available on open terms (in fact authors can select which Creative Commons licence the prefer), or to make the submitted-version available in an institutional repository after the embargo period of six months. Hitherto, this decision to make the article-as-published open access has mostly been taken by authors whose research is funded by one of the research councils (in the UK or EU). Evidence shows that "open access" publishing is good for authors: their articles are more likely to be accessed, cited in other academic work and featured in policy documents.

The amount of "open access" material published in the Journal looks set to expand. Cambridge University Press (CUP) is now making the possibility of choosing open access without paying an APC available to authors from institutions which have entered "read and publish" agreements with the Press (giving the institution the right to access CUP materials and, in turn, the right to publish openly and for free in CUP journals). The Cambridge Law Journal can therefore expect an increasing number of articles to appear in the Journal on open access terms.

On the whole, these changes are to be welcomed. However, they do introduce some uncertainties. The main challenge relates to the financial implications of the shift to full "open access". The various treasurers over the last 67 years have worked to ensure the Journal is not just solvent

135 Indeed, issues of open access publishing of legal scholarship have been under discussion since the mid-1990s. For an examination of the challenges open access raises for U.S. law reviews, see M.J. Madison, "The Idea of the Law Review: Scholarship, Prestige and Open Access" (2006) 10 Lewis \& Clark Law Review 901. For a more general overview, M.P. Eve, Open Access and the Humanities: Contexts, Controversies and the Future (Cambridge 2014).

136 Working Group on Expanding Access to Published Research Findings (also known as the Finch Committee) chaired by Dame Janet Finch. 
but profitable. ${ }^{137}$ At present, the Journal garners not insignificant remuneration through the Press, both from subscriptions and from consortia deals, and these monies are held in trust for purposes of legal research and education. Over the last decades, the trust has funded library purchases and doctoral scholarships. Ultimately, full open access will likely reduce the subscription side of the Journal's income: why would anyone pay to subscribe if all the material were accessible openly? Open access, arrangements, at least as facilitated through "read and publish agreements" entered by Cambridge University Press, do not appear to present an existential threat to the Journal, ${ }^{138}$ but may well affect its long-term prosperity and its charitable activities. But this prospect is one that most learned journals are now facing.

A third challenge facing the Journal relates not to technological disruption or shifts in business models but to social inclusivity. In reviewing the first century, it is only right to acknowledge that the Journal has a poor record on inclusivity, reflective of more general failings in the higher education system. ${ }^{139}$ On the whole, the Journal has been run (mostly) by white men, featured material written by men and has most likely been read by men. ${ }^{140}$ Here, primarily because of limitations with the available data, I focus on the question of gender.

During the 1940s, when the Journal was operated by the University Law Society, the Editorial Board included at least ten women students, ${ }^{141}$ but this was under 10 per cent of the student team. The first article written by a woman scholar seems to have been by the economist, Marjorie Tappan Hollond in $1933,{ }^{142}$ at which time she was a fellow of Girton College, as well as a lecturer in economics in the university. ${ }^{143}$ However, this remained exceptional for many decades (reflecting the fact that

137 The treasurers have been: Stanley Bailey (1955-59); Jack Hamson (1960-71); Sir John Baker (197382); Malcolm Clarke (1983-99); Neil Jones (2000-05); Jillaine Seymour (2006-08); Richard Moules (2009-10); Peter Turner (2010-19); Elizabeth Howell (2017-19); Louise Gullifer (2020-).

138 Indeed, my predecessor, John Bell, argued that "open access" would likely present journals that operated effective and rigorous peer review with the opportunity to signal quality of content, a key role in a world of proliferating information: J. Bell, “Open Access: The Journal Is Not Dead!” (2014) 14 Legal Information Management 143, 145.

139 Little is known about the changing numbers of women in legal academia before the end of the twentieth century, but the numbers were small. This can be seen in the well-meant comment of H.A. Hollond that he rejoiced "to see a sound piece of scholarship by a woman": [1930] C.L.J. 98, 98 (reviewing D. Whitelock (ed.), Anglo-Saxon Wills (Cambridge 1930)).

140 As recently as 2001, Celia Wells remarked that "Readers of [the journal Legal Studies] most likely are male, pale, middle-class and able-bodied": C. Wells, "Working Our Women in Law Schools" (2001) 21 Legal Studies 116, 116.

141 The following can be identified as women as they were denominated "Miss": June Murphy (Newnham, 1942); S.L. Whatmough (Girton, 1943), E. Stanley (Girton, 1944 and 1945), Rosemary Crofts and M. Holt (both Girton, 1946 and 1947); E.M. Skinner (Newnham, 1946); P. Stanley and V.M. Firth (both Girton, 1950); J. Lonsdale (Girton, 1951); R.E. Duckitt (Girton, 1952). It is not known what proportion of students at this time were women.

142 M. Tappan Hollond, "The Portuguese Banknote Case" [1933] C.L.J. 91.

143 Born in New York in 1895, Tappan studied at Bryn Mawr College and Columbia University, before lecturing part-time at the London School of Economics until 1926. She would go on to married Henry Arthur Hollond in 1929. Lecturer in Economics at Cambridge 
women legal scholars remained the exception). ${ }^{144}$ The eight articles published in the 1980 volume are all by men; only one article (of 12) in the 1990 volume was by a woman (Dr. Pippa Rogerson). The introduction of a "shorter articles" section in 1994 led to greater representation of women authors - for example, four of the nine short articles in the 1994 volume had women authors. When the numbers of female legal academics was first counted, in 1997, 40 per cent of legal academics were women (though numbers at professorial level were as low as 14 per cent). ${ }^{145}$ Reflecting this shifting demographic, in 2000, for example, four articles out of 15 were by (or co-authored by) women. ${ }^{146}$

Today, more women are involved in the Journal and more women scholars are published in it. As already noted, Cherry Hopkins was the convening note editor from 1996 to 2002 and most of the current team of note editors are now women; Dr. Pippa Rogerson (1998-2003) and Dr. Catherine Seville (2012-16) have held the post of book review editor; while Dr. Jillaine Seymour, Dr. Elizabeth Howell and Professor Louise Gullifer have held the Treasurer and Secretary position. ${ }^{147}$ In 2020 the Journal acquired its first woman General Editor, Professor Louise Gullifer (who, like Winfield and Bailey before her, holds the Rouse Ball Professorship). Although it is probably dangerous to rely on figures from any given year as representative, in 2010, eight of the 18 articles were authored or co-authored by women scholars. ${ }^{148}$

As the Faculty becomes more diverse and inclusive, we anticipate too that those working on the Journal will reflect this diversity. As far as authors are concerned, blind peer review ought to reassure them that the work we publish is assessed initially without regard to gender, ethnicity, disability or any other traditionally prejudicially treated and now protected characteristics.

However, it is clear there is still much work to be done in collection, and understanding, of data relating to the all relevant characteristics of those submitting manuscripts and those whose works end up being published, as well as reviewers. As we look forward to the Journal's second century, these matters are a priority for the Editors and Editorial Committee.

144 As late as 1998, Fiona Cownie bemoaned "the almost total lack of knowledge about the female members of the academic tribe which inhabits the territory of law": F. Cownie, "Women Legal Academics: A New Research Agenda?" (1998) 25 Journal of Law and Society 102, 109.

145 C. McGlynn, "Women, Representation and the Legal Academy" (1999) 19 LS 68, 75 (reporting a survey of UK law schools carried out in October 1997 which revealed that of 2157 legal scholars, 853 (40 per cent) were women; and of 301 law professors in the UK, 43 (14 per cent) were women).

146 These were Dr. Janet O'Sullivan, Dr. Stephanie Palmer, Joanna Miles and Dr. Catherine Barnard, all of whom were then (and remain) Cambridge Faculty colleagues.

147 Jillaine Seymour (2006-08); Dr. Elizabeth Howell (2017-19); and Professor Louise Gullifer (2020-).

148 Joyce Lee (Nanyang Technological University, Singapore), Professor Diane Birch (Nottingham), Claire McIvor (Birmingham), Eva Micheler (L.S.E.), Dr. Jennifer Davis (Cambridge), Professor Rachael Mulheron (QMUL), Professor Dawn Oliver (U.C.L.). 


\section{CONCLUSION}

As should be clear from this account, the Journal has prospered over its first century because of the efforts of a huge cast of actors, including Faculty editors (general editors, note editors, book review editors), student editors and the University Law Society (until 1953), the secretaries and treasurers, the other Editorial Committee members, the Journal's trustees, article, casenote and book-review authors (as well as those who offered their manuscripts unsuccessfully), the huge numbers of referees, our first research assistant, administrative support within the Faculty, as well as the work of printers and publishers (editors, content managers, peer review specialists, typesetters, copy-editors, proof-readers). A fraction of these are mentioned in this essay. It is my privilege, as the current Editor-in-Chief, to express the gratitude of the current editorial team for all the work that has been expended on the Journal since 1921. 